\title{
A mechanikus keringéstámogatás helyzete Magyarországon a Városmajor eredményeinek tükrében
}

\author{
Hartyánszky István, Sax Balázs, Fazekas Levente, Szabolcs Zoltán, \\ Horkay Ferenc, Heltai Krisztina, Németh Endre, Hüttl Tivadar, Pólos Miklós, \\ Daróczi László, Kőszegi Andrea, Tóth Roland, Barabás J. Imre, Benke Kálmán, \\ Kovács Péter, Merkely Béla
}

Semmelweis Egyetem, Városmajori Szív- és Érgyógyászati Klinika, Budapest

*Semmelweis Egyetem, Aneszteziológiai, és Intenzív Terápiás Klinika, Budapest

Levelezési cím: Dr. Hartyánszky István, PhD, M.Sc., Semmelweis Egyetem Városmajor Szív- és Érgyógyászati Klinika, Szívsebészeti Osztály, 1122 Budapest, Városmajor utca 68., E-mail:drharist@gmail.com

\begin{abstract}
A 25 éves magyar szívtranszplantáció sikertörténete mellé az elmúlt 5 évben felépítettük és programmá fejlesztettük a mechanikus keringéstámogatás terápiáját. Az elmúlt 5 évben történt fejlesztések, a Semmelweis Egyetem Városmajori Szív- és Érgyógyászati Klinikáján megépített Szívtranszplantációs és Szívelégtelenségi Intenzív Osztály, eszköz- és humánerőforrás fejlesztések tették lehetővé programunk kiteljesedését. Ma már a teljes mechanikus keringéstámogatási arzenállal, müszerparkkal rendelkezünk, amelynek segítségével minden indikációban és minden stratégiában ellátást tudunk nyújtani mind rövid, mind közép-, mint hosszú távon, akár a végleges müszív beültetésig.

Klinikánkon az elmúlt 5 évben 140 beteget kezeltünk összesen 185 esetben mechanikus keringéstámogató eszközökkel, valamennyi esetben súlyos terápia refrakter szívelégtelenségben: 50 alkalommal szívátültetés utáni primer graft-elégtelenség, 64 esetben krónikus végstádiumú szívelégtelenség akut exacerbációja, 41 esetben akut miokardiális infarktus okozta szívelégtelenség, 25 esetben szívmütét utáni postcardiotomiás szindróma, 4 esetben súlyos légzési elégtelenség, 1 esetben gyógyszer-intoxikáció miatt kialakult malignus kamrai ritmuszavar miatt alkalmaztuk a terápiát. A rövid és középtávú eszközök alkalmazásával a terápia refrakter kardiogén sokkban lévő betegek nagyobbik részét sikeresen juttattuk el a gyógyulásig vagy szivátültetésig, néhány esetben hosszú távú eszköz beültetéséig. 28 betegnél hosszú távú bal kamrát támogató eszközt ültettünk be a szívtranszplantációig történő áthidaló kezelésként, kiváló túléléssel.
\end{abstract}

Kulcsszavak: mechanikus keringéstámogatás, műszív, szívtranszplantáció, VAD, ECMO

State of the art of the mechanical circulatory device therapy in Hungary - the Városmajor experience Parallel to the 25 years of success in the Hungarian transplant program, in the last 5 years we built up a comprehensive mechanical circulatory support (MCS) program. Infrastructural and human resource development at the Heart and Vascular Center of Semmelweis University - including the establishment of a dedicated intensive care unit for heart failure therapies and heart transplantation - made the success of our advanced heart failure therapies program available. Now we provide the full spectrum of mechanical circulatory support in all indications and bridging strategies including short, mid and long term support.

In the last five years, we treated 140 patients with severe heart failure refractory to medical therapy with a total of 185 device implantations. Indications were primary graft failure after cardiac transplant $(n=50)$, acute decompensation of chronic heart failure $(n=64)$, post-myocardial infarction cardiogenic shock $(n=41)$, post-cardiotomy syndrome $(n=25)$, severe respiratory insufficiency $(n=4)$ and drug toxicity induced ventricular tachyarrhythmia $(n=1)$. We were able to bridge the majority of these patients to recovery, heart transplant or in certain cases until upgraded MCS therapy. We implanted 26 long term device as a bridge to transplant strategy with excellent results.

Keywords: mechanical circulatory support, heart transplantation, VAD, ECMO 


\section{Bevezetés}

25 éves a magyar szívátültetés. Ez a negyed évszázados forduló nemcsak az eltelt idő miatt nagy jelentőségü, hanem az ez alatt - föleg az utolsó öt évben - bekövetkező változások miatt, amelyekkel mára Magyarország a szívtranszplantációs aktivitás tekintetében Európa élvonalába került. Jellemző erre a fejlődésre, hogy az elmúlt öt évben több transzplantációt végeztünk, mint az előtte lévő 20 év alatt összesen (230 vs. 191). Jelenleg az éves szinten 50 körüli szívátültetéssel az egymillió lakosra eső transzplantációs számban Európa élvonalába kerültünk. Ebben az elmúlt öt évben számtalan egyéb fejlődésen is átesett programunk: csatlakoztunk az Eurotransplanthoz, a Semmelweis Egyetem kiemelt projektje lett a szívátültetés, számtalan és folyamatos fejlesztést végeztünk a donor-menedzsmentben, mütéti technikában és programmá fejlesztettük a mechanikus keringéstámogatást klinikákon.

Az Eurotransplanthoz való csatlakozásunk egyik közvetlen következménye a $\mathrm{HU}$ (high urgency, vagy magas rizikójú, akut) várólista-lehetőségének megnyílása volt, amelyet a várólista-aktivitás emelkedése követett. A várólista mortalitása a növekedés ellenére is jelenleg is csak megközelítőleg 15\% körüli, amelynek hátterében a megnövekedett aktivitás miatt részlegesen liberalizált recipiens elfogadás áll. Mind a HU-lista, mind pedig a várólista biztonságossá tételéhez elengedhetetlen fontosságú egy megfelelő mechanikus keringéstámogatási program megléte. A recipiens oldalról megnövekedett igény értelemszerủen magával hozta a donorelfogadás liberalizálását is. A donor- és a recipiens-kiválasztás liberalizációja miatt a transzplantáció utáni primer graft-elégtelenség előfordulása megemelkedett. A primer graft-elégtelenség a transzplantáció utáni vezető halálok a posztoperatív első évben. Megelőzéséhez jelentős változtatásokat vezettünk be a donor-menedzsmentben (endokrin reszuszcitáció, agresszív folyadék reszuszcitáció) és az intraoperatív myocardium protekcióban, ugyanakkor a transzplantációs paletta kiszélesedésével újabb betegcsoport is megjelent a recipiensek között, mégpedig a fixált pulmonalis hipertónia miatt transzplantációra eddig nem alkalmas betegek. Korszerủ szívtranszplantációs program elképzelhetetlen korszerủ mechanikus keringéstámogatási program nélkül, hiszen a végstádiumú szívelégtelenség szívsebészeti kezelésének eme két ága számos ponton csatlakozik egymáshoz. Ezek közül talán a legfontosabbak közé tartozik az ún. „HU-lista” és a transzplantációs vá- rólista biztonságosabbá tétele azzal, hogy a várólistán romló állapotú betegek átmeneti rövid távú keringéstámogatással stabilizálhatók, és a későbbiekben transzplantációra alkalmasabbá tehetők. Hasonlóan fontos aspektus a transzplantáció utáni primer graft-elégtelenség terápiája rövid vagy középtávú keringéstámogatással, vagy a magas pulmonalis rezisztencia miatt transzplantációra nem alkalmas betegek hosszú távú keringéstámogatással való eljuttatása a transzplantációig. Fontos megjegyezni, hogy ezeknél a betegeknél a tartós műszívkezelés végleges terápiás megoldást is jelenthet.

\section{A mechanikus keringéstámogatás alapjai}

Mechanikus keringéstámogatás indikációja alapvetöen akkor merül fel, amikor akut vagy krónikus szívelégtelenségben a szív pumpafunkciója oly mértékben lecsökken, hogy a perifériás, életfontosságú szervek vérellátása átmenetileg vagy tartósan károsodást szenvedhet. Az ekkor kialakuló circulus vitiousus gyógyszeresen már nem megszakítható, a keringési elégtelenség több szervi károsodáshoz vezethet, amely végső soron a beteg halálát okozza. Ezekben az esetekben a beteg életét csak a megfelelő időben elkezdett mechanikus keringéstámogatással van esélyünk megmenteni. A mechanikus keringéstámogatást összefoglalóan olyan készülékekre értjük, amelyeket a testbe beültetve a szív pumpafunkcióját támogatni vagy helyettesíteni tudjuk. Az eszközöket feloszthatjuk aszerint, hogy mennyi ideig képesek a keringést támogatni, így beszélhetünk rövid távú eszközökröl (1-7 nap) középtávú eszközökröl (1 héttöl - 2 hónapig) és tartós mechanikus keringést támogató eszközökről (évek). Az eszközöket csoportosíthatjuk áramlási profiljuk alapján is, így megkülönböztethetünk folyamatos (kontinua) áramlást biztosító és pulzatilis áramlást leadó készülékeket. A folyamatos áramlást leadó készülékek müködési elve a bennük lévő magnetikus térben lebegő és forgó propeller. A propellerek mechanikája alapján feloszthatjuk ezen eszközöket axiális és centrifugális pumpákra, mely készülékek előnye, hogy bennük mechanikai súrlódás - a mágneses térben való lebegésük következtében - elhanyagolható, így hosszú távú támogatásra alkalmasak, szemben a pulzatilis áramlást adó készülékekkel, amelyek mechanikus pumpálással továbbítják a vért, emiatt élettartamuk azonban limitált (pár hónap). Jól látszik, hogy a nómenklatúra igen bonyolult, éppen

Rövidítések:

AMI: akut miokardiális infarktus; ARDS: Acute Respiratory Distress Syndrome; BIVAD: Biventricular Assist Device; DCD: Donation after Cardiac Death; ECLS: Extracorporal Life Support; ECMO: Extracorporal Membrane Oxygenation; HTX: Szívtranszplantáció; IABP: Intraaortikus Ballonpumpa; INTERMACS: Interagency Registry for Mechanically Assisted Circulatory Support; LVAD: Left Ventricular Assist Device; PCCS: Post Cardiotomy Cardiogenic Shock - szív-tüdőmotorról való leállási nehézség, hemodinamikai sokk; PECLA: Pumpless Extracorporeal Lung Assist; PCl: Percutan Coronary Intervention; PGD: Primary Graft Disfunction - szívtranszplantácó utáni primer graft-elégtelenség; RVAD: Right Ventricular Assist Device; TAVI: Transcatether Aortic Valve Implantation - katéteres aortabillentyű-implantáció; VSD: Ventricular Septal Defect - kamrai szeptumdefektus 
ezért fontos a megfelelő elnevezések használata. Az orvosi köznyelvben előforduló múszív-elnevezés szigorú értelemben véve azt a ma még nem teljesen elérhető, döntően kísérleti stádiumban lévő keringést támogató eszközt jelenti, amely teljes mértékben implantálható és mindkét szívfél támogatására alkalmas, azonban használhatjuk a tartós balkamra-támogatásra beültetett (LVAD), teljesen implantálható készülékekre is.

A mechanikus keringéstámogató rendszerek müködési alapelve tulajdonképpen a szívmotor müködési elvén alapul, ennek megfelelően alkotórészei is nagyjából a szívmotor felépítésének felelnek meg. Ezek alapján szükségünk van kanülökre, amelyek segítségével a beteg testéből elvezetni, illetve visszavezetni tudjuk a vért, szükségünk van egy csőrendszerre, amellyel öszsze tudjuk kötni a kanült a pumpával, szükségünk van egy motor részre, amelynek segítségével a véroszlopot kinetikus energiával tudjuk ellátni és amennyiben szükség van rá, a rendszerbe beépíthető oxigenátor is, hogy a beteg vérét oxigénnel elláthassuk. Mindezek alapján képesek vagyunk a kieső tüdő vagy szív funkciójának pótlására, lehetőségünk van a szív bal vagy jobb felének vagy mindkét kamrájának támogatására alkalmas rendszerek összeállítására. Abban az esetben, hacsak a kieső tüdő funkcióját kell pótolnunk megfelelő szív pumpafunkció mellett, kialakíthatunk egy csak a vénás rendszerbe beültetett támogató rendszert, amikor a vénás vért a vena femoralisból kivezetve, oxigenátor segítségével oxigenizálva, pumpa segítségével a szív jobb pitvarába juttatjuk. Így a tüdőn már oxigenizált vér folyik át, majd jut a bal pitvarba és a bal kamrán keresztül a szisztémás keringésbe. Ezt a rendszert V-V ECMO-nak (veno-venosus Extracorporal Membrane Oxigenisation) nevezzük. Amikor mind a tüdő mind a szív pumpafunkciója támogatásra szorul, akkor az előbbihez hasonló rendszert építhetünk fel azzal a különbséggel, hogy a pumpa segítségével a már oxigenizált vért nem a vénás keringésbe juttatjuk vissza, hanem az artériás rendszerbe, így a kis vérkört kihagyjuk. Ennek az eszköznek az elnevezése $\mathrm{V}$-A ECMO (veno-arteriosus Extracorporal Membrane Oxigenisation). A V-V ECMO-terápia időtartama általában pár hét lehet, míg a V-A ECMO-terápia időtartama 7-10 napban maximalizált. A V-A ECMO-terápiához szükséges kanülöket beültethetjük perifériás erekbe, vagy a mellkas megnyitásával centrális nagyerekbe. Ezek alapján beszélhetünk perifériás, illetve centrális ECMO-támogatásról. Alapvető különbség a kettő között, hogy míg centrális támogatásnál a nagyerekben anterográd áramlást biztosítunk, addig perifériás kanülálás során retrográd áramlást. Ezek alapján jól látható, hogy perifériás $\mathrm{V}-\mathrm{A}$ ECMO-terápiával a bal kamra utóterhelését emeljük, így ez a terápia - bár alkalmas a perctérfogat leadásán keresztül a beteg életben tartására - a bal kamra pihentetésére, detenzionálására nem alkalmas.

Abban az esetben, ha a tüdő funkciója nem károsodott, annak feladatát pótolnunk nem kell és csak a szív pum-
1. TÁBLÁZAT. A mechanikus keringéstámogatás elvi lehetőségei. A fel nem oldott rövidítéseket lásd a rövidítések jegyzékénél

\begin{tabular}{|l|l|}
\hline $\begin{array}{l}\text { Keringés/légzéstámogatás } \\
\text { módszere }\end{array}$ & $\begin{array}{l}\text { Terápiás } \\
\text { időtartam hossza }\end{array}$
\end{tabular}

Pulmonalis funkció támogatása oxigenátor segítségével

Pumpless Extracorporeal Lung

Assist (PECLA)

Extracorporal Membrane napok-hetek

Oxygenation (ECMO)

$\mathrm{V}-\mathrm{V}$ ECMO

Kardiális és pulmonalis funkció támogatása oxigenátor segítségével

Extracorporeal Life Support (ECLS)

V-A ECMO

napok-hetek

Kardiális és pulmonalis funkció támogatása oxigenátor nélkül

Mechanikus keringéstámogatás

pumpával - VAD

LVAD

hetek-hónapok

RVAD

(évek LVAD)

BIVAD

pafunkcióját kell támogatnunk, úgynevezett VAD (vetricular assist device - kamrai keringést támogató) eszközöket ültethetünk be. Amennyiben a bal kamrát kell támogatnunk, akkor úgynevezett LVAD, amennyiben a jobb kamrát RVAD, amennyiben mindkét kamrát kell támogatnunk BiVAD-készüléket ültethetünk be. Az ezen készülékekkel nyújtható támogatás ideje egy héttől két hónapig tartó időszakra lehetséges. Mind ECMO, mind VAD-terápiánál testen kívüli készülékekröl beszélünk. A betegbe csak a kanülöket ültetjük be, a csőszett, a pumparész és az azt energiával ellátó konzol a betegen kívül helyezkedik el.

Amennyiben tartós (többéves) támogatásra van szükségünk - mert a beteg aktuálisan nem alkalmas transzplantációra vagy az esetleges pumpafunkció restitúciója hosszú időt vehet igénybe - tartós bal kamrai keringést támogató eszköz beültetésére lehet szükség, amely eszközök jellemzője, hogy teljes mértékben implantálhatóak. A lehetséges keringéstámogató eszközöket az. 1. táblázatban foglaltuk össze.

A mechanikus keringéstámogató eszközök széles palettája igen változatos kezelési stratégiákat tesz lehetővé. A különböző kórlefolyások adta különböző igényeknek különböző eszközökkel felelhetünk meg, gyakran azonban az is előfordul, hogy egy betegnél egymás után több típusú eszköz használatára van szükség. A keringéstámogató eszközök stratégiájának felosztásában a bridge (híd) szó központi helyet foglal el, utalva a mechanikus keringéstámogató terápia átmeneti voltára. A klinikai gyakorlatban leggyakrabban előforduló esetben a pumpafunkció átmeneti károsodása miatt van szük- 
ség keringéstámogatás elindítására. Ebben az esetben azt várjuk, hogy a pumpafunkció rövidtávon megjavuljon, és a keringéstámogatást megszüntethessük. Ennek a stratégiának az elnevezése a Bridge-to-Recovery és ekkor általában V-A ECMO-terápiát használunk. Előfordulhat olyan akut helyzet, amikor nincs megfelelő információnk a beteg általános állapotáról és/vagy kardiális státuszáról, de akut életmentő ECMO-terápiát indítunk, hogy a beteget életben tarthassuk és ezalatt megfelelő információt szerezhessünk arról, hogy kezelését hogyan folytassuk. Ennek az indikációnak az elnevezése a Bridge-to-Decision. Ebben az indikációban is ECMO-terápiát alkalmazhatunk. Előfordulhat olyan helyzet, amikor végstádiumú szívelégtelenségben szenvedő beteg olyan állapotba kerül, hogy transzplantációra nem alkalmas. Az ilyenkor még időben elindított mechanikus keringéstámogatás - mely jellemzően VAD-terápia - a beteget alkalmassá teheti arra, hogy transzplantáció várományos lehessen, és így a várólistáig eljuthasson. Ennek a stratégiának az elnevezése a Bridge-to-Candidacy. Amennyiben már várólistán lévő betegnél alakul ki súlyos pumpafunkció-romlás, amely a transzplantáció eredményességét is veszélyeztetheti, szóba jön Bridge-to-Transplantation indikációval VAD-beültetés és mechanikus keringéstámogatás, amelynek segítségével a beteg ideális állapotban

\section{TÁBLÁZAT. Stratégiai lehetőségek a mechanikus keringés-} támogató eszközök használata kapcsán

Bridge to recovery

Akut keringési elégtelenség (pl. koronária-intervenció, akut miokardiális infarktus kapcsán)

Szívmotorról való leállás sikertelensége (perioperatív low output szindróma)

Egyéb módon uralhatatlan légzési diszfunkció (pl. ARDS esetén)

\section{Bridge over procedure}

Instabil állapotba kerülő beteg támogatására (pl. koronáriaintervenció közben)

Bridge to decision

Akut helyzetben (pl. újraélesztés kapcsán, kérdéses neurológiai státusz esetén)

Keringéstámogatás mellett időt nyerünk a beteg stabilizálására/további vizsgálatok elvégzésére

Bridge to bridge

Az aktuális kezelés nem elégséges, a további javulás magasabb szintű kezelést igényel

Bridge to candidacy

Átmeneti keringéstámogatás súlyos állapotú beteg esetén transzplantációs listára helyezéshez

Bridge to HTX

Transzplantációs várólistán szereplő beteg stabil állapotban tartására a szívátültetésig

Destination therapy

Mechanikus keringéstámogató eszköz végleges alkalmazása kerülhet transzplantációra. Amennyiben végstádiumú szívelégtelen betegnél kizáró ok miatt nem jön szóba transzplantáció, vagy testsúlya és vércsoportja miatt donorszív csak nagyon nehezen található számára, a transzplantáció alternatívájaként szóba jön Destination Therapy stratégiával tartós (több év) keringéstámogatás, „müszív” terápia alkalmazása. Az egyes stratégiák felsorolását lásd a 2. táblázatban.

\section{Betegek és módszerek}

Klinikánkon az ECMO (rövid távú) támogatásra használt készülék a Deltastream (Medos Medizintechnik $A G)$, középtávú VAD-terápiához pedig a Centrimag (Abbott Corp.) készülékét használjuk. Mindkét eszközre jellemző a moduláris felépítés: a csőszettekböl ki-, illetve beépíthető az oxigenátor, mindkettő alkalmazható kis- és nagyvérkörben egyaránt és centrifugális pumpafejjel rendelkeznek.

A Városmajori Szív- és Érgyógyászati Klinikán hosszú távú keringéstámogatásra alkalmazott eszközeink a HeartMate II, amely teljesen implantálható, bal kamra támogatására alkalmas, axiális elven működő pumpa és a legújabb generációs HeartMate 3 készülék, amelynek pumpája centrifugális elven működik, teljes mág-

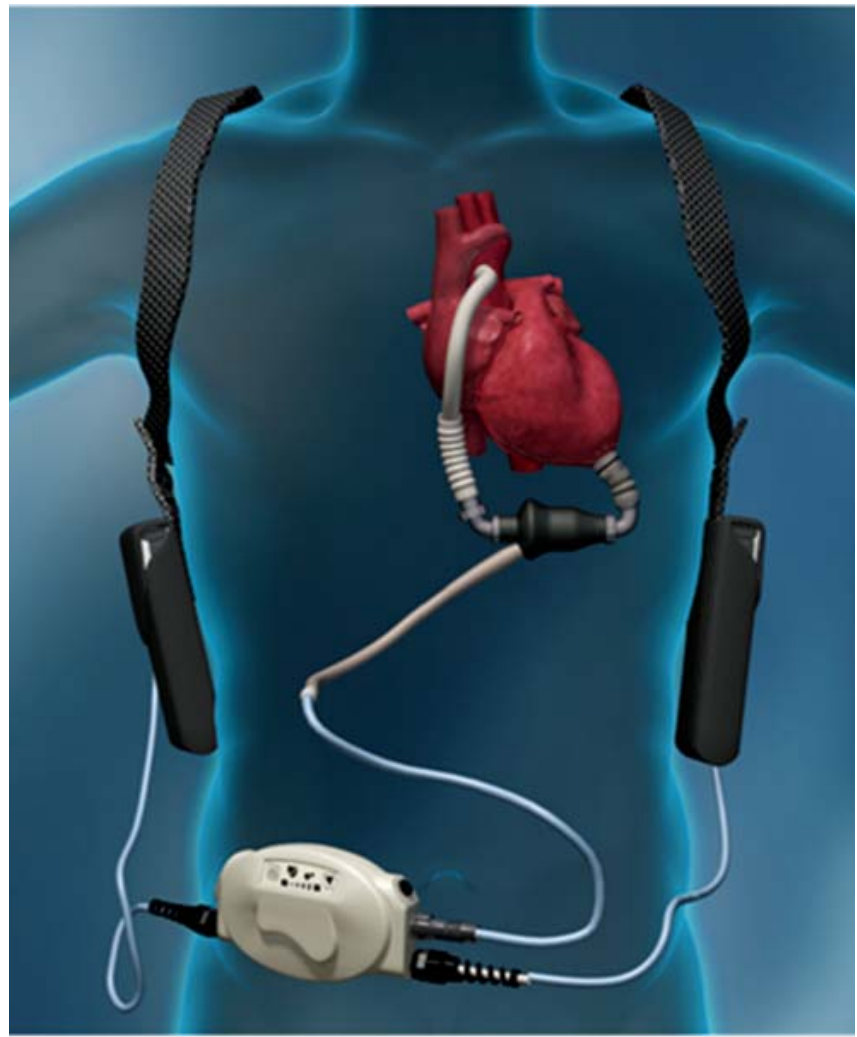

1. ÁBRA. A Thoratec HeartMate II LVAD. A készülék részei: inflow kanül a bal kamrában, pumpa, outflow kanül az aortába, drive-line összeköttetés a külső vezérlőegységgel, külső tápegységek 
neses levitációval (Abbott Corp.). Ezek a készülékek teljes mértékben implantálhatóak, csak az energiaellátásukhoz szükséges drive-line kábelt kell a beteg hasfali bőrén keresztül kivezetni a külső tápegységekhez. A HeartMate II készülék felépítését az 1. ábra mutatja. Adataink feldolgozásához a klinikánkon létrehozott és bevezetett CorDB adatbázis rendszerét használtuk, amelynek segítségével hosszú távú után követéses vizsgálatot végeztünk, eredményeinket Kaplan-Meiré-analízissel vizsgáltuk.

\section{Eredmények}

Klinikánkon a mechanikus keringéstámogató program megkezdése - 2012 óta - és annak programmá fejlesztése alatt az elmúlt öt évben 140 beteget 185 alkalommal kezeltünk mechanikus keringéstámogató eszközökkel.

ECMO-terápiát 111 esetben végeztünk, ebböl 33 alkalommal szívátültetés után kialakult akut primer graft-elégtelenség miatt, 18 alkalommal szívmütét utáni postcardiotomiás szindróma (szívmütét utáni leállás nehézség), 37 esetben akut miokardiális infarktus utáni akut keringési elégtelenség, 14 alkalommal végstádiumú szívelégtelen betegek akut keringésmegingása (INTERMACS 1-2), 4 esetben súlyos légzési elégtelenség, 1 esetben gyógyszermérgezés miatt kialakult malignus kamrai ritmuszavar, 3 esetben szövődményes TAVI-beültetés miatt, valamint 1 esetben az ECMO-készülék trombózisa miatt ECMO-cserét végeztünk. Az alkalmazott ECMO-terápia során a tíznapos mortalitásunk megközelítette a $40 \%$-ot. Amennyiben a terápiát 10 nap után is folytatni kényszerültünk, úgy a halálozás drasztikusan emelkedett (2. ábra). Postcardiotomiás szindrómában alkalmazott ECMO-terápia mortalitása magasabbnak, 50\%-nak bizonyult, az akut miokardiális infarktusban végzett ECMO-kezelés mortalitása $70 \%$ fölött volt. A gyógyszer-intoxikációkban végzett 1 ECMO-támogatásunk sikeres volt. A leghosszabb ECMO-kezelés 15 napig tartott.

Jobbszívfél-támogató eszközt (RVAD) 21 esetben ültettünk be: 4 alkalommal tartós „műszív”-kezelés átmeneti jobb szívfél támogatására, 3 esetben postcardiotomiás szindróma miatt szívműtét után, 1 esetben pedig akut miokardiális infarktust követő keringési elégtelenség miatt. A többi 13 esetben transzplantációt követő primer graft-elégtelenség miatt szorultunk ilyen típusú keringéstámogatás beültetésére. Ebböl a csoportból összesen 7 beteget veszítettünk el. A 7 beteg közül 3 beteget még az RVAD-terápia során a 3., 17. és 18. napon. További 4 beteget sikeres leszoktatás után a későbbiekben veszítettünk el.

Mind a bal, mind a jobb szívfél támogatását igénylő esetekben 21 alkalommal végeztünk BiVAD-beültetést. Egy alkalommal az implantácó már súlyos keringési instabilitásban, több szervi elégtelenségben történt,

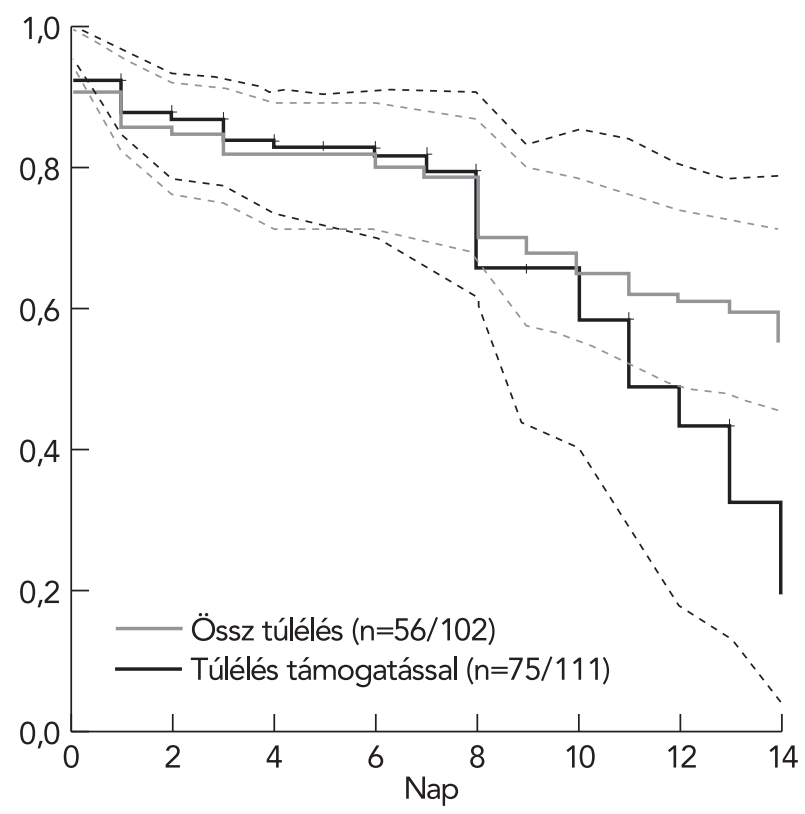

2. ÁBRA. A 14 napos ECMO-kezelés Kaplan-Meier-túlélés görbéje. Fekete görbe: az eszközös támogatás túlélése (végpont a kezelés befejezése, vagy a beteg elvesztése). Szürke görbe: az össz-túlélést jelöltük (végpont a beteg elvesztése). Egy-egy beteg több különböző konfigurációban kerülhetett ECMO-kezelésre. Zárójelben az esetszám és túlélők aránya a kezelés 14. napján. Szaggatott vonallal a 95\%-os konfidencia-intervallumot jelöltük

ezért tartós kettős kamratámogatást biztosító pulzatilis BiVAD-készüléket ültettünk be, amellyel a beteget sikeresen támogattuk egy évig. A 21 BiVAD-beültetésből 13 alkalommal súlyos keringési sokkban lévő betegeket támogattuk (INTERMACS 1-2), 3 alkalommal szívmütét után postcardiotomiás szindrómában ültettük be, 4 esetben transzplantáció utáni primer graft-elégtelenségben alkalmaztuk és 1 alkalommal akut miokardiális infarktus utáni keringési elégtelenségben használtuk. A BiVAD-beültetett betegeink közül 13-at tudtunk transzplantációig eljuttatni, amely betegeink közül hetet veszítettünk el 2, 42, 44, 188, 209, 342 és 377 napos támogatás után. A leghosszabb BiVAD-kezelés 174 nap volt.

Teljesen implantálható, tartós keringéstámogatást nyújtó „müszív” LVAD-terápiát összesen 28 betegnél végeztünk. $A$ beültetés indikációja valamennyi esetben súlyos szívelégtelenség volt (Intermacs 1-5 stádiumban) és 1 esetben akut miokardiális infarktus okozta súlyos kamrai ritmuszavar és pumpafunkció-zavar. A hosszú távú kezelés alatt hat betegnél észleltünk pumpa-trombózisra utaló hemolízist, illetve egy esetben agyi embolizációt. Ezen betegeknél két esetben végeztünk sikeres pumpacserét a beültetés utáni 155 . és 1218. napon. A többi négy beteg esetében HU-listáról szívátültetés történt (3. ábra). Az összes pumpatrombózis esetünk HeartMate II-es készülékkel történt, a 2015 novembere óta rendszeresen alkalmazott 


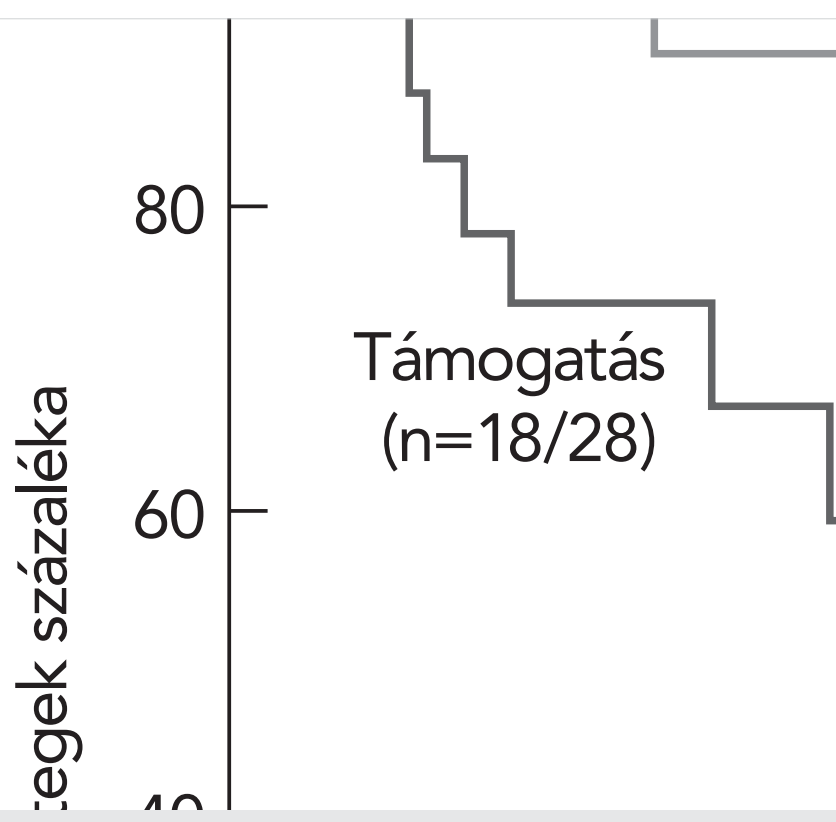

3. ÁBRA. LVAD kompetitív kimenetel. Zárójelben az esetszám és a túlélök aránya a kezelés teljes tartama alatt (LVAD - Left Ventricular Assist Device, HTX - szívtranszplantáció)

HeartMate 3 készülékkel hasonló szövődményt nem tapasztaltunk. Ebből a tartós LVAD-beültetett betegcsoportból összesen öt beteget veszítettünk el: hármat szívátültetés utáni korai posztoperatív szakban, egyet ismételt drive-line infekció utáni szepszis miatt, egyet pedig roncstüdő mellett fellépett uralhatatlan légzési elégtelenség miatt.

\section{Megbeszélés}

Az elmúlt évtized a szívelégtelenség terápiájában a mechanikus keringéstámogatásról szólt. Jól megfigyelhető ez a tendencia a nemzetközi transzplantációs kongresszusokon is, ahol mára a tudományos témáknak több mint a fele a mechanikus keringéstámogatásról szól. A szívtranszplantációval már elértük lehetőségeink határát, a donorok száma érdemben nem vagy csak nehezen emelhető (DCD-donáció bevezetése, donorkritériumok kiszélesítése). Ugyanakkor folyamatos fejlesztések és invenciók történnek műszívterápiában. Mára már elérhető közelségbe került, hogy akár mind a két kamrát teljesen implantálható készülékkel támogatni tudjuk egyszerre és elérhető közelségbe került a technikai fejlesztések hatására, hogy a keringéstámogató eszközök energiaellátása transzkután úton történhessen, így a továbbiakban a folyamatos fertőzéses kaput fenntartó bőrön kivezetett drive-line energiaforrásra már nem lesz szükség. Amennyiben ez az utóbbi két fejlesztés is megtörténik, akkor a szívtranszplantációval teljesen egyenértékü, akár azt kiváltó technika is a kezünkbe kerülhet.
Klinikánkon alkalmazott mechanikus keringéstámogatás mind stratégiájában, mind az alkalmazott eszközök előfordulásában jól tükrözi a nemzetközi tendenciákat. A leggyakrabban alkalmazott eszköz az ECMO-terápia volt, hiszen akut esetben, vagy amikor nem áll rendelkezésünkre megfelelő mennyiségű információ a beteg állapotáról, ez az első választandó és legkönnyebben elindítható terápiás modalitás.

A mechanikus keringéstámogatás eredményességének vizsgálatakor nagyon fontos a paradigmaváltás. Ebben a betegcsoportban nem indulhatunk ki a mortalitási adatokból, hiszen például az ECMO-betegeknek közel felét elveszítettük a terápia során. Ha ebből a szempontból nézzük, akkor egy igen magas mortalitási terápiáról van szó, amelynek létjogosultsága megkérdőjelezhető lenne. Éppen ezért a túlélési adatokat kell előtérbe helyezni, mivel ez egy olyan betegcsoport ahol a betegek 100\%-a meghalt volna terápiás beavatkozás nélkül, vagyis 10 betegből nem ötöt elveszítettünk, hanem ötnek az életét tudtuk megmenteni.

A minél könnyebb elérhetőség miatt klinikánkon fast deployment ECMO-stratégiát alkalmazunk, amelynek lényege, hogy egy ECMO-készülék folyamatosan összeszerelt és feltöltött állapotban áll és amennyiben akár a mütőben, akár a hemodinamikai laborban, akár az intenzív osztályon újraélesztés közben szükség lenne rá, a készülék azonnal felhasználható. Jól látható, hogy az egyes kezelési stratégiák egymásra épülnek és ezek első, legalsó, azonban legszélesebb spektrumát az ECMO adja (1). Mindezek alapján szükséges lenne az ECMO-terápia országos kiszélesítése is, amelyhez alapul első körben a szívsebészeti centrumok szolgálhatnának. Szükség lenne ezen centrumok eszközös felszerelésére és megfelelö oktatással használatuk elsajátítására $(2,3)$. Többek között azért is lenne logikus lépés a szívsebészeti centrumokban történő ECMO-rendszer felépítése, mivel ezek a centrumok találkoznak első körben akut miokardiális infarktus mechanikus szövődményeivel (VSD), vagy pedig a szívmútét után kialakuló akár 2-6\% prevalenciájú postcardiotomiás szindrómával $(4,5)$. További széles körü alkalmazási területe lenne az ECMO-terápiának az akut miokardiális infarktushoz társuló akut balszívfél-elégtelenség. Legújabb ajánlások szerint kardiogén sokkos beteg ellátásában az intraaortikus ballonpumpa egyre inkább háttérbe szorul $(6,7)$, sőt megjelentek már olyan adatok is, amelyek már nem is támogatják a ballonpumpa használatát $(8,9)$. Ezzel szemben a hemodinamikai laborban minden adott a perifériás nagyerek kanülásához, ezek segítségével perifériás ECMO-terápia elindításához, így a teljes perctérfogatot leadva a beteg állapota stabilizálható, a tervezett beavatkozás elvégezhető, amennyiben szükséges a beteg további terápiás döntésig juttatható, akár szállítható is $(10,11,12)$.

A mechanikus keringéstámogatási rendszer következő lépcsőfoka a kamrai assist device (VAD, LVAD, RVAD, BiVAD) készülékek. Ezen eszközök beültetése már jelentős technikai hátteret igényel, a betegek hosszú 
távú terápiájához szoros együttmüködésre van szükség a társszakmák között (kardiológia, intenzív terápia és aneszteziológia, szívsebészet, érsebészet). A kamrai támogató eszközök alkalmazása kiemelt, arra dedikált centrumokban javasolt. Szóba jöhet a korábban ECMO-val stabilizált betegek szállítása ezekbe a centrumokba és itt további ellátásuk megszervezése.

A tartós bal kamrai keringéstámogató készülék (műszív) szerepe a fejlett országokban a szívdonorok számának csökkenésével és ezzel együtt a transzplantációk számának stagnálásával egyre nagyobb szerepet kap (13). Az intézetünkben az elmúlt öt év alatt szerzett tapasztalatok kedvezőek $(15,16,17)$. A nemzetközi tendenciáknak látszólag ellentmondani látszik, hogy Magyarországon az elmúlt öt évben a szívtranszplantációk száma mintegy háromszorosára nőtt. Az ellentmondás oka nem feltétlenül a magyar donorok magasabb számával magyarázható, hanem azzal, hogy a donor-koordináció sikeres és hatékony megszervezésével ma már sokkal több potenciális donort tudunk elérni. Ezzel jelentős lemaradást dolgoztunk le. Figyelemre méltó ugyanakkor, hogy az évről évre várólistára kerülő betegek száma pontosan megegyezik a transzplantáltak számával, holott a nyugati országokban a listára kerülők száma a transzplantáltak számának többszöröse. Ez rámutat arra, hogy Magyarországon a várólistára kerülő betegek száma sajnos messze elmarad a kívánatostól. Részben ezzel is magyarázható, hogy a tartós müszívkezelésre kerülő betegek száma (2016-ban 6) a transzplantáltak számához képest (2016-ban 51) hazánkban meszsze elmarad a nemzetközi számoktól (Németországban 2014-óta évről-évre több müszívbeültetés történik, mint szívtranszplantáció) (14). A mechanikus keringéstámogatás az utolsó lehetőségként bevethető életmentő eszközből ma már a szívtranszplantáció reális alternatívája számos, súlyos szívelégtelen beteg számára.

\section{Következtetések}

Mára már elmondhatjuk, hogy klinikánkon a mechanikus keringéstámogatást programmá alakítottuk, a teljes terápiás arzenállal rendelkezünk, azt minden indikációban és minden stratégiában alkalmazni tudjuk. Ezekkel a modern eszközökkel már számos olyan akut és krónikus szívelégtelenségben szenvedő betegen segíteni tudtunk, akiket korábban elveszítettünk volna.

A szívelégtelenségnek az alapellátás, vagyis a háziorvosi szinten történő korai felismerése, majd az erre épülő kardiológiai, illetve szívelégtelenség-ellátás hálózatának kiépítése elengedhetetlen a rendszer működése szempontjából. Tény, hogy a végstádiumú szívelégtelen betegek egy csoportja szívtranszplantációra átmenetileg vagy véglegesen nem alkalmas, de pontosan ezek azok a betegek, akiknél a legnagyobb egészség-nyereség lenne elérhető a mellkasba beültethető hosszú távú mechanikus keringéstámogató eszközökkel.
További feladatunk, hogy széles körü felvilágosító tevékenységet folytassunk a várólista megfelelő feltöltéséhez, ezáltal a transzplantációs aktivitás fokozásához, amely a későbbiekben együtt járhat a mechanikus keringéstámogatás számának emelkedésével is, hogy minél több beteghez, végső soron országos szinten mindenkihez el tudjuk juttatni ezt a terápiás modalitást.

Irodalom

1. Fermin R, Swanevelder J, Ferreira M. Extracorporeal membrane oxygenation (ECMO) in South Africa. Southern African Journal Of Critical Care 2013; 29: 3-5. Doi 10.7196/sajcc.165

2. Cheng R, Hachamovitch R, Kittleson M, et al. Complications of extracorporeal membrane oxygenation for treatment of cardiogenic shock and cardiac arrest: a meta-analysis of 1,866 adult patients. Ann Thorac Surg 2014; 97(2): 610-6. Doi 10.1016/j.athoracsur.2013.09.008 3. Mohite PN, Sabashnikov A, Patil NP, et al. Short-term ventricular assist device in post-cardiotomy cardiogenic shock: factors influencing survival. J Artif Organs 2014; 17(3): 228-35. Doi 10.1007/s10047-014-0773-1 4. Stub D, Bernard S, Pellegrino V, et al. Refractory cardiac arrest treated with mechanical CPR, hypothermia, ECMO and early reperfusion (the CHEER trial). Resuscitation 2014, pii: S0300-9572(14)00751-5. [Epub ahead of print] Doi 10.1016/j.resuscitation.2015.05.018

5. Gregoric ID, Mesar T, Kar B, et al. Percutaneous ventricular assist device and extracorporeal membrane oxygenation support in a patient with postinfarction ventricular septal defect and free wall rupture. Heart Surg Forum 2013; 16(3): E150-1. Doi 10.1532/HSF98.20121123

6. Anderson JL, Adams CD, Antman EM, et al. 2011 ACCF/AHA Focused Update Incorporated Into the ACC/AHA 2007 Guidelines for the Management of Patients With Unstable Angina/Non-ST-Elevation Myocardial Infarction: a report of the American College of Cardiology Foundation/ American Heart Association Task Force on Practice Guidelines. Circulation 2011; 123(18): e426-579. Doi 10.1161/CIR.0b013e318212bb8b 7. Steg PG, James SK, Atar D, et al. ESC Guidelines for the management of acute myocardial infarction in patients presenting with ST-segment elevation. Task Force on the management of ST-segment elevation acute myocardial infarction of the European Society of Cardiology (ESC). Eur Heart J 2012; 33(20): 2569-619. Doi 10.1093/eurheartj/ehs215

8. Khan $\mathrm{MH}$, Corbett BJ, Hollenberg SM. Mechanical circulatory support in acute cardiogenic shock. F1000Prime Rep 2014; 1(6): 91. Doi 10.12703/P6-91 9. Thiele H, Zeymer U, Neumann FJ, et al. Intraaortic Balloon Pump in cardiogenic shock I| (IABP-SHOCK II) trial investigators. Intra-aortic balloon counterpulsation in acute myocardial infarction complicated by cardiogenic shock (IABP-SHOCK II): final 12 month results of a rando mised, open-label trial. Lancet 2013; 382: 1638-45. Doi 10.1016/S01406736(13)61783-3

10. Combes A, Leprince P, Luyt CE, et al. Outcomes and long-term quality-of-life of patients supported by extracorporeal membrane oxygenation for refractory cardiogenic shock. Crit Care Med 2008; 36(5): 1404-11. Doi 10.1097/CCM.0b013e31816f7cf7

11. Tsao NW, Shih CM, Yeh JS, et al. Extracorporeal membrane oxygenation-assisted primary percutaneous coronary intervention may improve survival of patients with acute myocardial infarction complicated by profound cardiogenic shock. J Crit Care 2012: 27(5): 530.e1-11. Doi $10.1016 /$ j.jcrc. 2012.02.012

12. Lebreton G, Sanchez B, Hennequin JL, et al. The French airbridge for circulatory support in the Carribean. Interact Cardiovasc Thorac Surg 2012; 15(3): 420-5. Doi 10.1093/icvts/ivs215

13. Calfee JE, Sudduth G. Are Medical Devices Turning the Corner against Heart Failure? Health Policy Outlook 2011; 2. http://www.aei.org/publication/are-medical-devices-turning-the-corner-against-heart-failure/\#mbl 14. Krabatsch T, Knosalla C, Potapov E. Should LVAD Implantation Be the New Gold Standard for Terminal Heart Disease? ISHLT Links 2013; 11(4). http://www.ishlt.org/ContentDocuments/2013MarLinks Krabatsch.html\#

15. Sax B. Müszívkezelés Magyarországon. Háziorvosi Továbbképző Szemle 2014

16. Fazekas L, Sax B, Hartyanszky I, Polos M, Horkay F, Varga T, Merkely B. Mechanical circulatory support saves lives -- three years' experience of the newly established assist device program at Semmelweis University. Budapest, Hungary. Orv Hetil 2015; 156(13): 521-527. doi: 10.1556/oh.2015.30115 Doi 10.1556/oh.2015.30115

17. Fazekas L, Szabolcs Z, Hartyanszky I, Polos M, Merkely B. Mechanikus keringéstámogatás és szívtranszplantáció Magyarországon a nemzetközi tendenciák tükrében. Cardiologia Hungarica 2015; 45: 14. 